Jurnal Ilmu-Ilmu Peternakan 25 (2): 62 - 70

ISSN: 0852-3581

E-ISSN: 9772443D76DD3

CFakultas Peternakan UB, http://jiip.ub.ac.id/

\title{
Analisis respon stakeholders terhadap program pemberdayaan masya- rakat home industry pengolahan ceker dan bulu ayam di Kelurahan Kampung Mandar Banyuwangi
}

\author{
Rizka Romi Alfisyahrin, Siti Azizah dan Eko Nugroho \\ Fakultas Peternakan Universitas Brawijaya \\ J1. Veteran Malang 65145 Jawa Timur \\ rizkaromialfisyahrin@yahoo.co.id
}

\begin{abstract}
The research was conducted from November $27^{\text {th }}$ to December $30^{\text {th }}, 2014$ in Kampung Mandar Banyuwangi, East Java. The objectives of the research were to identify the community response to the empowerment program. Thirty respondents were selected as respondents of this program. Primary and secondary data were collected by survey method using a structured questionnaire. Respondents' responses were analyzed by descriptive analysis. The study found that attitude variable indicated that respondents agreed with the empowerment program and had a desire to continue the program. Perception of the respondents showed that respondents had a high understanding about the topic given in the program and in line to the respondents' need. With regards to participation variable, the research showed that respondents were active in taking decision to attend the program.
\end{abstract}

Keywords: attitude, perception, participation, empowerment

\section{PENDAHULUAN}

Daging ayam menduduki peringkat pertama dalam memenuhi kebutuhan daging unggas di Indonesia. Banyaknya jumlah daging ayam yang dikonsumsi berbanding lurus dengan hasil samping dan limbah yang dihasilkan oleh Rumah Potong Ayam (RPA). Hasil samping tersebut masih memiliki nilai ekonomis seperti bulu, darah, jerohan (organ viscera) dan non karkas (kepala dan ceker). Namun hasil samping dan limbah yang dihasilkan masih belum banyak dimanfaatkan oleh masyarakat khususnya di Kelurahan Kampung Mandar Kabupaten Banyuwangi.

Kelurahan Kampung Mandar terletak di Kabupaten Banyuwangi Jawa Timur yang mengalami pertumbuhan pesat dalam bidang pariwisata. Potensi unggas khususnya ternak ayam menempati urutan pertama dengan jumlah ternak berturut-turut yaitu ayam buras sebanyak 1.247.721 ekor, ayam petelur sebanyak 658.970 ekor dan ayam pedaging sebanyak 3.552.750 ekor (Dinas Peternakan Jawa Timur, 2015). Berdasarkan data tersebut dapat dipastikan potensi hasil samping dan limbah yang dihasilkan juga sangat banyak. Rumah potong ayam (RPA) yang berlokasi di Kelurahan Kampung Mandar sebanyak 5 yang berskala rumah tangga. Namun, hasil samping RPA tersebut belum dimanfaatkan secara optimal dan hanya dibuang ke sungai yang bermuara di Selat Bali. Disisi lain, Kabupaten Banyuwangi 
sedang gencar mempromosikan pariwisata khususnya Pantai Boom yang berada di Kelurahan Kampung Mandar.

Sumber daya manusia yang kurang memadai menyebabkan hasil samping tersebut tidak bernilai walaupun dapat menambah income peternak jika dimanfaatkan secara optimal. Upaya untuk memperbaiki mutu hidup dan kesejahteraan peternak maupun warga Kelurahan Kampung Mandar salah satunya adalah dengan memberikan inovasi-inovasi baru yang dapat diberikan melalui program pemberdayaan. Sejalan dengan hal tersebut, civitas akademika Fakultas Peternakan Universitas Brawijaya melaksanakan program pemberdayaan bagi masyarakat Kelurahan Kampung Mandar melalui program Iptek bagi Masyarakat (IbM) DIKTI.

Inovasi yang telah disampaikan kepada warga Kelurahan Kampung Mandar difokuskan pada pengolahan bulu ayam menjadi tepung bulu sebagai sumber protein pada pakan ternak. Sedangkan ceker ayam diolah menjadi produk gantungan ceker ayam dan kripik ceker ayam. Program pemberdayaan tersebut melibatkan berbagai stakeholders yang terdiri dari warga Kelurahan Kampung Mandar, Kepala dan perangkat kantor Kelurahan, organisasi pemuda dan penyuluh. Oleh karena itu, penelitian ini bertujuan untuk mengetahui respon stakeholders terhadap program pemberdayaan masyarakat melalui home industry RPA di Kelurahan Kampung Mandar Banyuwangi.

\section{MATERI DAN METODE}

\section{Lokasi dan waktu penelitian}

Penelitian ini dilaksanakan di Kampung Mandar, Kecamatan Kota, Kabupaten Banyuwangi pada tanggal 27 November sampai 30 Desember 2014.

\section{Populasi dan sampel}

Populasi responden dalam penelitian ini adalah stakeholders yang ikut serta dalam pelaksanaan program pemberdayaan, antara lain Kepala dan perangkat kantor kelurahan, pemilik RPA, ketua dan anggota organisasi pemuda dan masyarakat Kelurahan Kampung Mandar. Teknik total sampling digunakan dalam penentuan 30 orang responden penelitian seperti yang ditunjukkan pada Tabel 1.

Tabel 1. Jumlah responden penelitian

\begin{tabular}{lc}
\hline \multicolumn{1}{c}{ Stakeholders peserta program pemberdayaan } & Jumlah \\
\hline Warga Kelurahan Kampung Mandar & 24 \\
Pemilik RPA & 4 \\
Perangkat kantor Kelurahan Kampung Mandar & 2 \\
\hline Total & 30 \\
\hline
\end{tabular}

\section{Metode penelitian}

Metode survei digunakan untuk memperoleh data primer dan sekunder. Data primer dikumpulkan melalui interview kepada stakeholders menggunakan kuesioner, sedangkan data sekunder diperoleh dari instansi yang terkait dengan penelitian ini. Data- data tersebut diolah dan dibandingkan dengan teori yang telah ada.

\section{Pengumpulan data}

Tingkat ukuran yang dipakai dalam pengukuran variabel menggunakan skala Likert dimana responden dihadapkan pada beberapa pertanyaan kemudian diminta 
memberikan jawabannya (Algifari, 2003). Skala Likert yang digunakan pada kuesioner adalah 1 sampai 5 dengan penjelasan 1 adalah jawaban yang paling tidak sesuai dengan tujuan program pemberdayaan sedangkan 5 adalah jawaban yang paling sesuai dengan tujuan program pemberdayaan.

\section{Analisis data}

Analisis deskriptif kualitatif digunakan untuk mengetahui respon stakeholders yang meliputi sikap, persepsi dan partisipasi terhadap program pemberdayaan yang dilakukan di Kelurahan Kampung Mandar. Selanjutnya setiap butir pertanyaan dari sikap, persepsi dan partisipasi diuji dengan validitas dan reliabilitasnya. Cara pengukuran tingkat validitas item- item pertanyaan kuesioner terhadap tujuan pengukuran adalah dengan melakukan korelasi antar skor item pertanyaan dengan skor variabel (Ghozali, 2005).

Variabel jenis kelamin, usia, tingkat pendidikan dan pendapatan dianalisis menggunakan analisis tabulasi silang (cross tabulation) pada program SPSS 16.0. Pembagian kategori usia berdasarkan psikologi perkembangan oleh Sabri (2001), sedangkan standar UMR yang digunakan adalah UMR tahun 2015 Kabupaten Banyuwangi yaitu sebesar Rp.1.426.000 berdasarkan Pergub Jatim no. 72 Tahun 2015. Alur analisis data dapat dilihat pada Gambar 1.

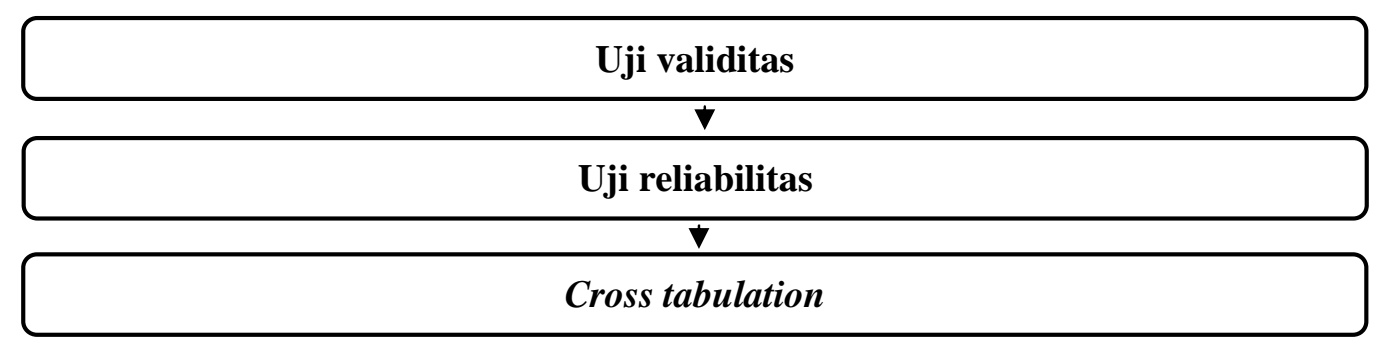

Gambar 1. Alur analisis data

\section{HASIL DAN PEMBAHASAN}

\section{Keadaan umum lokasi penelitian}

Kelurahan Kampung Mandar merupakan salah satu kelurahan yang berada di wilayah Kecamatan Banyuwangi, Kabupaten Banyuwangi, Provinsi Jawa Timur. Sebagian besar wilayah Kelurahan Kampung Mandar merupakan pesisir dimana penduduknya bermata pencaharian sebagai nelayan, pengusaha skala kecil seperti pemilik Rumah Potong Ayam (RPA), pedagang dan pegawai swasta.

Kampung Mandar memiliki kondisi sosial cukup baik yang ditunjukkan dari masih lestarinya budaya gotong-royong. Selain itu, berbagai kegiatan rutin selalu diadakan seperti rapat, arisan maupun kegiatan keagamaan. Akses menuju Kelurahan Kampung Mandar sangat bagus dan lancar karena letaknya yang dekat dengan pusat Kota Banyuwangi dan tempat wisata Pantai Boom.

\section{Karakteristik responden}

Karakteristik responden dibedakan menurut usia, jenis kelamin, tingkat pendidikan dan pendapatan. Karakteristik responden disajikan pada Tabel 2. 
Tabel 2. Karakteristik responden

\begin{tabular}{lcc}
\hline \multicolumn{1}{c}{ Karakteristik responden } & Jumlah & Persentase (\%) \\
\hline Jenis kelamin & & 63 \\
\hline Laki-laki & 19 & 37 \\
Perempuan & 11 & \\
\hline Usia (tahun) & 3 & 10 \\
\hline Remaja (16-21) & 21 & 70 \\
Dewasa awal (21-40) & 6 & 20 \\
Dewasa tengah (40-60) & & \\
\hline Tingkat pendidikan & 3 & 10 \\
SD & 6 & 50 \\
SMP & 15 & 3 \\
SMA & 1 & 16 \\
Diploma & 5 & 76,7 \\
Sarjana & & 23,3 \\
\hline Pendapatan (UMR 2015= Rp 1.426.000) & 23 & \\
\hline < UMR & 7 & \\
zUMR &
\end{tabular}

Sumber : Data primer diolah tahun 2015

*Sabri (2001)

Sikap responden terhadap program

Sikap merupakan salah satu variabel yang diamati dalam mengetahui respon responden terhadap program pemberdayaan ini. Sikap responden terhadap program pemberdayaan bisa dilihat pada Tabel 1 .

Tabel 1. Sikap responden terhadap program pemberdayaan

\begin{tabular}{|c|c|c|c|c|c|c|}
\hline \multirow{2}{*}{$\mathrm{Y}_{1}$ (Sikap) } & \multicolumn{5}{|c|}{ Skor Likert } & \multirow[t]{2}{*}{ Rata-rata } \\
\hline & 1 & 2 & 3 & 4 & 5 & \\
\hline$Y_{1.1}$ setuju dengan diadakannya program & - & - & - & 14 & 16 & 4,53 \\
\hline$Y_{1.2}$ ketertarikan dengan program & - & - & 10 & 8 & 12 & 4,00 \\
\hline $\mathrm{Y}_{1.3}$ manfaat program bagi peserta & - & 3 & 13 & 4 & 10 & 3,7 \\
\hline $\mathrm{Y}_{1.4}$ materi yang diberikan dalam program & - & 5 & 12 & 5 & 8 & 3,53 \\
\hline $\mathrm{Y}_{1.5}$ keinginan untuk keberlanjutan program & - & - & - & 14 & 16 & 4,53 \\
\hline Rata-rata & - & & & & & 4,06 \\
\hline $\begin{array}{l}1=\text { tidak setuju } \\
2=\text { kurang setuju } \\
3=\text { cukup setuju }\end{array}$ & $\begin{array}{l}4= \\
5=\end{array}$ & tuj & & & & \\
\hline
\end{tabular}

Tabel 1 menunjukkan bahwa rata-rata skor Likert untuk pernyataan responden setuju dengan diadakannya program adalah 4,53 atau dapat diartikan responden menjawab sangat setuju karena pada kenyataannya program pemberdayaan masyarakat sangat dibutuhkan khususnya untuk masyarakat dengan golongan ekonomi menengah kebawah atau berpenghasilan rendah. Tingkat keinginan yang tinggi dari masyarakat peserta program menjadi faktor utama keberhasilan program pemberdayaan.

Ketertarikan responden terhadap program pemberdayaan ditunjukkan 
dengan nilai skor rata-rata 4,00 yang berarti sangat tertarik dengan program pemberdayaan ini karena belum pernah dilakukan sebelumnya di Kelurahan Kampung Mandar. Terkait dengan manfaat program bagi peserta, hasil penelitian menunjukkan bahwa nilai rata-rata yang dihasilkan yaitu 3,7 yang artinya responden merasa program bermanfaat untuk mendapatkan keterampilan baru dan dapat menambah pendapatan keluarga jika melanjutkan program ini. Harapan dari adanya program pemberdayaan yaitu selain mendapatkan wawasan dan keterampilan baru, responden juga mampu memasarkan produk hasil olahan.

Sehubungan dengan materi yang diberikan dalam program, nilai rata-rata yang diperoleh adalah 3,53 yang berarti responden menilai materi yang diberikan sesuai dengan kebutuhan warga dan keadaan lingkungan Kelurahan Kampung Mandar. Nilai rata-rata keinginan untuk keberlanjutan program adalah 4,53 yang artinya responden menginginkan adanya keberlanjutan program ini. Kreatifitas masyarakat Kelurahan Kampung Mandar sebelum adanya program ditunjukkan dengan adanya "Sanggar Pemuda Kreatif" yang menjadi wadah hasil karya pemuda di Kelurahan Kampung Mandar. Program pemberdayaan ini memotivasi masyarakat untuk memanfaatkan hasil samping maupun limbah RPA yang dapat bernilai jual tinggi. Satriani, dkk (2013) menyatakan masyarakat yang memiliki kesadaran dan motivasi tinggi akan mampu menjadi masyarakat mandiri yang dapat menciptakan lapangan kerja sendiri dan melakukan perubahan positif terhadap lingkungannya.

\section{Persepsi responden terhadap program}

Rakhmat (2000) menyatakan bahwa persepsi merupakan pengalaman tentang obyek, peristiwa atau hubungan-hubungan yang diperoleh dengan menyimpulkan informasi dan menafsirkan pesan. Notoatmodjo (2007) menambahkan bahwa persepsi seseorang terhadap suatu objek akan mempengaruhi perilakunya. Tabel 2 menunjukkan persepsi responden terhadap program pemberdayaan masyarakat.

Tabel 2. Persepsi responden terhadap program pemberdayaan masyarakat

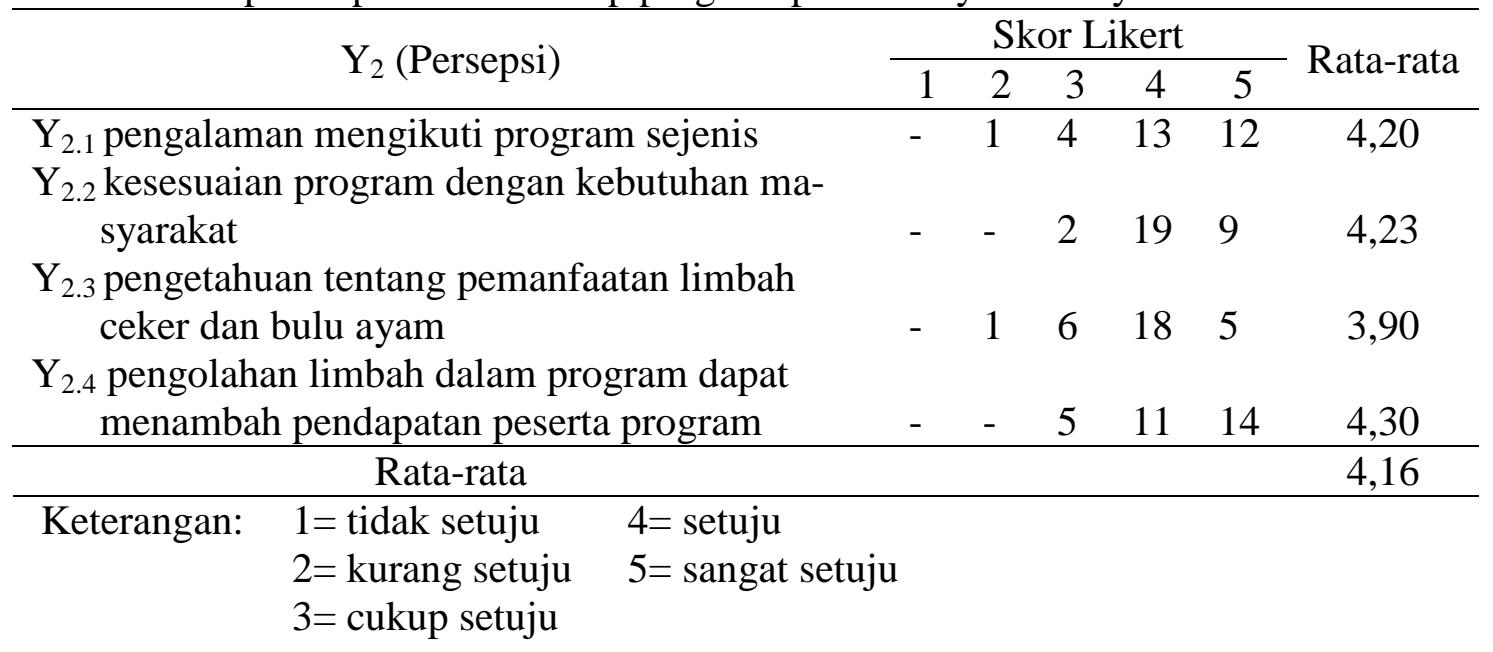


Tabel 2 menunjukkan bahwa nilai rata-rata pengalaman responden mengikuti program sejenis adalah 4,20 yang artinya sebagian besar responden pernah mengikuti program pemberdayaan hanya satu kali sehingga program ini sesuai dengan kebutuhan responden. Hal ini mengindikasikan bahwa pengalaman yang dimiliki warga Kelurahan Kampung Mandar cukup baik karena hampir semua responden pernah mengikuti program pemberdayaan walaupun berbeda materinya. Soemirat (2003) menyatakan bahwa pengalaman masa lalu dapat mempengaruhi faktor kebutuhan dan kepribadian. Selain itu, latar belakang budaya merupakan nilai yang dianut suatu kelompok pada daerah tertentu dan akan berpengaruh pada cara menginterprestasikan hal baru yang telah didapatkan.

Nilai rata-rata kesesuaian program dengan kebutuhan masyarakat adalah 4,23 yang berarti sesuai dengan kondisi, lingkungan dan adat masyarakat Kelurahan Kampung Mandar. Kesesuaian program dengan kebutuhan peserta tentunya berpengaruh terhadap keberlanjutan program yang telah dilaksanakan. Kesesuaian program dilihat dari beberapa aspek seperti keadaan lingkungan, ekonomi, budaya maupun jumlah pengangguran dan pekerja. Selain itu, pemilihan materi juga diputuskan dari hasil musyawarah dengan kepala kelurahan dan ketua pemuda Kelurahan Kampung Mandar. Beberapa hal tersebut yang akan menjadi penilaian awal apakah program yang dilaksanakan akan berhasil dan berlanjut. Selain itu tingkat keberhasilan juga dapat dilihat dari tingkat kesejahteraan masyarakat yang semakin meningkat dengan melanjutkan pengolahan yang telah diajarkan saat program dilaksanakan.

Pengetahuan responden tentang pengolahan limbah RPA sangat baik.
Hal ini didukung dengan nilai rata-rata sebesar 3,90 yang artinya responden pernah mendapatkan informasi, pernah melihat namun belum pernah melakukan pengolahan tersebut. Hasil penelitian ini didukung oleh Rakhmat (2000) yang menyatakan bahwa persepsi individu dibatasi oleh (1) perbedaan pengalaman, motivasi dan keadaan; (2) perbedaan kapasitas alat indera dan (3) perbedaan pandangan, nilai dan kepercayaan. Pengolahan yang telah banyak diketahui oleh responden adalah tentang pengolahan ceker ayam yang dijadikan kripik. Sebagian responden mengetahui tentang pemanfaatan bulu dari limbah RPA dapat digunakan sebagai tepung bulu. Namun hampir seluruh responden belum pernah mengetahui produk gantungan kunci ceker ayam. Program pemberdayaan ini bermanfaat karena responden mendapatkan ilmu, keterampilan dan produk baru yaitu gantungan kunci ceker ayam.

Hasil wawancara dengan responden menunjukkan nilai rata-rata 4,30 yang menandakan bahwa responden menyatakan setuju jika keuntungan dari hasil pengolahan limbah RPA mencapai 30-60\% dibandingkan jika limbah tidak diolah. Adanya peningkatan pendapatan keluarga peserta menjadi daya tarik utama para peserta mengikuti program pemberdayaan. Pemanfaatan limbah RPA tersebut diharapkan dapat mengurangi pengangguran di Kelurahan Kampung Mandar, menjadikan Kelurahan Kampung Mandar lebih bersih dan membuka lapangan pekerjaan baru.

\section{Partisipasi responden terhadap program}

Tampubolon (2013) menyatakan bahwa partisipasi merupakan kesediaan untuk membantu berhasilnya suatu program sesuai dengan kemampuan 
setiap orang tanpa berarti Partisipasi responden pada program mengorbankan kepentingan sendiri. pemberdayaan bisa dilihat pada Tabel 3.

Tabel 3. Partisipasi responden pada program pemberdayaan

\begin{tabular}{|c|c|c|c|c|c|c|}
\hline \multirow{2}{*}{$\mathrm{Y}_{3}$ (Partisipasi) } & \multicolumn{5}{|c|}{ Skor Likert } & \multirow{2}{*}{ Rata-rata } \\
\hline & 1 & 2 & 3 & 4 & 5 & \\
\hline $\begin{array}{l}Y_{3.1} \text { pengambilan keputusan pelaksanaan pro- } \\
\text { gram }\end{array}$ & 2 & 14 & 13 & 1 & - & 2,43 \\
\hline $\mathrm{Y}_{3.2}$ keikutsertaan perencanaan program & 7 & 14 & 8 & 1 & - & 2,1 \\
\hline $\begin{array}{l}Y_{3.3} \text { ikut serta dalam pelatihan dari awal hingga } \\
\text { akhir program }\end{array}$ & 2 & 16 & 9 & 1 & 2 & 2,5 \\
\hline $\begin{array}{l}Y_{3.4} \text { memberikan masukan atau kritik saat } \\
\text { pelaksanaan program }\end{array}$ & 8 & 14 & 6 & 1 & 1 & 2,1 \\
\hline $\begin{array}{l}\mathrm{Y}_{3.5} \text { memberi bantuan berupa materi maupun te- } \\
\text { naga saat pelaksanaan program }\end{array}$ & - & - & 2 & 10 & 18 & 4,53 \\
\hline $\begin{array}{l}\mathrm{Y}_{3.6} \text { manfaat yang diperoleh selama mengikuti } \\
\text { program }\end{array}$ & - & - & 4 & 5 & 21 & 4,57 \\
\hline $\begin{array}{l}\text { Y }_{3.7} \text { adanya rekan bisnis untuk memasarkan pro- } \\
\text { duk hasil olahan }\end{array}$ & 2 & 10 & 6 & 6 & 6 & 3,13 \\
\hline $\mathrm{Y}_{3.8}$ kontinyuitas pemanfaatan program & - & - & 2 & 12 & 16 & 4,47 \\
\hline Rata-rata & & & & & & 3,23 \\
\hline $\begin{array}{l}1=\text { sangat kurang berpartisipasi } \\
2=\text { kurang berpartisipasi } \\
3=\text { cukup berpartisipasi }\end{array}$ & & & & & basi & \\
\hline
\end{tabular}

Partisipasi responden dalam pengambilan keputusan pelaksanaan program menunjukkan nilai rata-rata 2,43 yang berarti masih tergolong rendah. Hal ini dapat disebabkan para peserta belum memiliki pengetahuan dan pengalaman dalam program seperti ini, sehingga rasa takut dan ragu masih menjadi alasan utama mengapa tidak memberikan saran sebagai penilaian partisipasi mereka. Hasil yang sama ditunjukkan pada partisipasi responden pada perencanaan program dimana skor rata-rata yang diperoleh yaitu 2,1 yang menunjukkan kurangnya partisipasi warga dalam perencanaan program.

Partisipasi responden tidak hanya dalam perencanaan program namun berlanjut dalam tahap pelaksanaan. Nilai rata-rata kehadiran responden dalam pelaksanaan program adalah 2,5. Hasil ini menandakan bahwa responden mengikuti pelaksanaan program dari awal pelatihan pembuatan kripik ceker ayam, gantungan kunci ceker ayam dan pembuatan tepung bulu sebanyak 3-4 kali dari jumlah 9 kali pertemuan. Hal tersebut dikarenakan waktu pelaksanaan program tidak bisa disesuaikan dengan jadwal kerja seluruh responden.

Partisipasi responden dalam hal pemberian saran dan kritik terhadap pelaksanaan program tergolong rendah yang ditunjukkan dengan nilai rata-rata skor 2,1. Pada umumnya yang aktif dalam berpendapat hanya orang-orang tertentu saja. Kebanyakan responden selalu setuju dan mengikuti pendapat yang disampaikan rekan mereka, terlebih yang disampaikan oleh tokoh masyarakat dan fasilitator. Menurut Baba dkk (2011), hanya petani tertentu saja yang memiliki keberanian dalam mengemukakan pendapat utamanya mereka yang memang telah terbiasa 
dalam mengemukakan pendapat. Adapun bagi peternak yang belum terbiasa terkadang malu untuk mengemukakan pendapat.

Indikator pemberian bantuan berupa materi maupun tenaga saat pelaksanaan program memperoleh nilai rata-rata 4,53 yang berarti responden berpartisipasi dengan memberikan bantuan berupa tenaga dan materi pada saat pengolahan ketiga produk. Bentuk tenaga dalam hal ini yaitu terjun langsung mengikuti pelatihan pembuatan produk sedangkan materi berbentuk bantuan seperti makanan dan minuman yang disediakan selama program berlangsung.

Nilai rata-rata hasil penelitian mengenai manfaat setelah mengikuti program adalah 4,57 yang mengindikaskan bahwa program ini sangat bermanfaat bagi responden. Manfaat yang diperoleh responden setelah mengikuti program ini antara lain pengetahuan baru dalam pengolahan limbah serta keterampilan baru untuk menghasilkan produk yang memiliki harga jual cukup tinggi dan menjadikan Kelurahan Kampung Mandar lebih berkembang dan mandiri.

Pada program ini tidak hanya diajarkan mengenai pembuatan produk namun juga cara pemasaran produk yang baik. Adanya rekan bisnis untuk memasarkan produk hasil olahan juga menjadi penunjang dalam pemasaran produk yang dihasilkan. Hasil penelitian menunjukkan skor rata-rata 3,13 yang artinya responden rata-rata memiliki dua orang rekan bisnis dalam memasarkan produk hasil pengolahan pada program ini. Selanjutnya rekan bisnis tersebut diharapkan dapat membantu memasarkan produk hasil olahan warga Kelurahan Kampung Mandar.

Semangat warga Kelurahan Kampung Mandar dalam melanjutkan program pemberdayaan ini sangat tinggi. Hal tersebut ditunjukkan dari nilai rata-rata 4,47 yang berarti stakeholders melanjutkan hampir semua produk yang diajarkan karena selain menambah pendapatan, keberlanjutan program juga dapat dijadikan sebagai lapangan pekerjaan baru.

\section{KESIMPULAN}

Penelitian ini menyimpulkan bawah respon responden menunjukkan sikap setuju dengan adanya program pemberdayaan guna meningkatkan taraf hidup dan kemandirian masyarakat Kelurahan Kampung Mandar. Persepsi responden terhadap program pemberdayaan tergolong baik dan partisipasi responden saat pengambilan keputusan, perencanaan, pelaksanaan dan keberlanjutan program juga terbilang cukup baik.

\section{UCAPAN TERIMA KASIH}

Penulis mengucapkan terima kasih kepada DIKTI yang telah memberikan bantuan finansial terhadap penelitian ini melalui program IbM. Selain itu, penulis juga berterima kasih kepada seluruh pihak yang terlibat dalam penelitian ini khususnya para responden yang tidak bosan melayani pertanyaan-pertanyaan yang diajukan oleh penulis.

\section{DAFTAR PUSTAKA}

Algifari. 2003. Statistik induktif untuk ekonomi dan bisnis. Edisi kedua. UPP AMP YKPN. Yogyakarta.

Baba, S., Isbandi, Mardikanto, $\mathrm{T}$ dan Waridin. 2011. Faktor-faktor yang mempengaruhi tingkat partisipasi peternak sapi perah dalam penyuluhan di Kabupaten Enrekang. JITP. 1 (3): 75-81.

Dinas Peternakan Jawa Timur. 2015. Data statistik populasi ternak Kab/Kota di Jawa Timur. http://www.disnak.jatimprov.go.id 
/web/layananpublik /datastatistik. Diakses tanggal 8 Agustus 2015.

Ghozali, I. 2005. Aplikasi analisis multivariat dengan program SPSS. Badan Penerbit Universitas Diponegoro. Semarang.

Notoatmodjo, S. 2007. Promosi kesehatan dan ilmu perilaku. Rineka Cipta. Jakarta.

Rakhmat, J. 2000. Metode penelitian komunikasi. Remaja Rosdakarya. Bandung.

Sabri, M. A. 2001. Pengantar psikologi umum dan perkembangan. Pedoman Ilmu Jaya. Jakarta.

Satriani, G dan Ihsan, M. 2003. Persepsi dan sikap masyarakat terhadap penerapan program pemberdayaan di sekitar sub daerah aliran sungai Miu (kasus program SCBFWM di Desa Simoro Kecamatan Gumbasa Kabupaten Sigi). Jurnal Warta Rimba. 1 (1): 1-10.

Soemirat, S. 2003. Dasar-dasar public relations. Rosda. Jakarta.

Tampubolon, J. H. 2013. Respon warga binaan terhadap program pemberdayaan komunitas adat terpencil oleh Dinas Kesejahteraan dan Sosial, Provinsi Sumatera Utara di Desa Sionom Hudon Selatan Kecamatan Parlilitan Kabupaten Humbang Hasudutan. Repository Universitas Sumatera Utara. 